Seção "Sugestões de Leitura".

10\% Humano: Como Os Micro-organismos São A Chave Para A Saúde Do Corpo E Da Mente por Alanna Collen (Autor), Ivo Korytowski (Tradutor). Há muito mais coisas em seu corpo do que você poderia imaginar. Cerca de 100 trilhões delas, para ser mais exato. Para cada célula humana em nosso organismo, há outras nove impostoras, pegando carona. Você não é formado apenas de carne e osso, sangue e músculo, mas também de bactérias e fungos. Não é um indivíduo, mas uma colônia - um ecossistema. Somos apenas $10 \%$ humanos. Até pouco tempo atrás, os micróbios eram vistos como invasores, inimigos, parasitas. Estávamos decididos a exterminá-los. Mas a ciência vem revelando uma história bem diferente: os micro-organismos comandam nosso corpo e evoluíram numa relação de estreita simbiose com os humanos - e é impossível ser saudável sem eles. Neste livro instigante e revolucionário, a bióloga Alanna Collen apresenta as últimas pesquisas científicas e mostra de que forma os micróbios que habitam o corpo determinam nosso peso, o funcionamento de nosso sistema imunológico e até mesmo nossa saúde mental. Além disso, mostra como as doenças modernas obesidade, autismo, transtornos mentais, problemas intestinais, alergias e doenças autoimunes - teriam uma causa comum: o fato de não estarmos cultivando uma boa relação com nossa colônia pessoal de micro-organismos. Esta nova perspectiva traz uma boa notícia: ao contrário de nossas células humanas, nossa colônia microbiana pode ser alterada para melhor. Depois de 10\% Humano, você nunca mais vai enxergar seu corpo e sua vida - da mesma forma.

A Incrível Conexão Intestino Cérebro. Descubra a Relação Entre as Emoções e o Equilíbrio Intestinal por Camila Rowlands (Autor), Guillermo Elizarrarás (Tradutor). "Nunca antes tinha sido revelado com tal claridade a enorme verdade que encerra o aforismo "'"somos o que comemos"'. Porque nunca antes tinha visto tão claramente que o medo, a ira, o amor, a felicidade, a paz do espírito, o equilíbrio emocional... (e m definitivo, o que somos e o que vivemos) são assuntos das vísceras e que talvez, nelas habite e se expresse o esquivo subconsciente. Até há pouco tempo acreditava-se que o comando absoluto sobre o resto dos órgãos era exercido pelo cérebro, que desde o alto dirigia, por exemplo, a atividade intestinal. Assim, o intestino era considerado pela ciência tal qual mero subordinado que acatava as ordens desse chefe todo poderoso que habita a zona nobre da torre. Contudo, hoje se sabe que o intestino tem o mesmo grau de importância que o cérebro cranial. Isso é assim, a ponto de que se fala de um segundo cérebro e não em sentido metafórico. O intestino é, literalmente, nosso segundo cérebro."

\title{
Agenda de Eventos
}

Ganepão 2018: 8 ICNO/CBNC - International Conference of Nutritional Oncology / Congresso Brasileiro de Nutrição em Câncer e 2o NEXSA Congresso Internacional de Nutrição, Exercício e Saúde 
12 a 15 de Junho de 2018

Centro de Convenções Rebouças - São Paulo, SP

https://www.ganepao.com.br/congresso/2018/pt 